good progress was made, both in the development of the exhibited collections and in the less spectacular research conducted in the laboratories. That this work should now have been brought almost to a stop is regrettable, if inevitable. The announcement recently made that certain galleries are to be reopened to the public, and that special exhibits of current interest are being arranged, will be widely welcomed.

\section{Biology in Schools}

THE latest report of the Joint Committee of the Four Secondary Associations shows useful and, indeed, necessary work for education in the way of criticism, protest and suggestion. Complacency about the success of evacuation is now being reduced. Authorities who commandeer schools for officials and leave school buildings in a defective state have much to answer for. Such unwise economy is strange, after reckless expenditure elsewhere. A subsidiary subject syllabus is printed which a sub-committee of biologists has suggested for a London Higher School Certificate, since separate syllabuses for botany and zoology are regarded as unsatisfactory. This scheme for biology includes six important subjects, from histology to heredity and ecology, though the last-named is reduced to the study of fauna and flora in a restricted area. A practical examination and a written paper, each for three hours, are proposed, but the former, if ill-done, will not mean failure in the subject as a whole. The wide ground is well covered but, as the average teaching time for the whole of the syllabus, including practical work, is three hours a week, is there not too much to get through ? Ambitious programmes tend to produce shallow knowledge which is soon lost.

\section{Cave Man in Colorado}

Excavation of a cave near Durango, Colorado, it is anticipated, may afford evidence for an approximate early dating of basket-maker culture in the southwestern States. The investigation was carried out on behalf of the Carnegie Institution of Washington by Earl H. Morris. Evidence of occupation, according to a report circulated by Science Service of Washington, D.C., was found below three feet of accumulated debris. There were indications that the inhabitants had lived in one-room structures, with mud-coated floors and fire-pits, though how these constructions were built was not detected. Corn and pumpkins were grown, but the principal mode of subsistence apparently was by hunting.

The most significant find, however, consisted of charcoal, from which tree-ring sequences have been constructed each covering a period of at least one hundred years. These are not only independent of one another, but also of any known Indian tree-ring datings. As these last have now been carried back to about A.D. 150, unless, as Dr. A. V. Kidder has suggested, conditions in this area were entirely different from the normal for northern Colorado, this constitutes valid evidence for Basket-maker occupation of the cave at not less than approximately two thousand years ago.

\section{A Preparation for the Control of Bleeding}

A FAT-SOLUBLE vitamin, known as vitamin $\mathrm{K}$, is indirectly concerned with blood coagulation, will reduce the clotting time of blood in cases of prothrombin deficiency, and will check certain forms of hæmorrhage, such as occur in obstructive jaundice and occasionally in new-born babies. Vitamin $\mathrm{K}$ is found naturally in alfalfa and hog's liver fat, it has been isolated and its chemical composition determined. Several related but simpler compounds are known possessing a physiological action similar to the natural vitamin $K$, and one of these-a methylnaphthaquinone-has been introduced for use in medicine by Glaxo Laboratories, Ltd., Greenford, Middlesex, under the name "Kapilon". Kapilon has been found to be a valuable agent for reducing bleeding in obstructive jaundice and in neo-natal hæmorrhage.

\section{Institution of Electrical Engineers : Scholarships}

THE following scholarships are open for award by the Institution of Electrical Engineers during 1940 : Duddell Scholarship (value $£ 150$ per annum, tenable for three years), open to British subjects less than nineteen years of age on July 1, for a whole-time day course in electrical engineering ; F'erranti Scholarship (value $£ 250$ per annum, tenable for two years), open to British subjects less than twenty-six years of age on July 1, who are students or graduates of the Institution, for whole-time research or postgraduate work of an electrical engineering nature; Swan Memorial Scholarship (value £120, for one year), open to British subjects less than twentyseven years of age on July 1, for whole-time research or post-graduate work of an electrical engineering nature; Silvanus Thompson Scholarship (value $£ 100$ per annum and tuition fees, tenable for two years), for works' employees who are the sons of parents of limited means, open to British subjects less than twenty-two years of age on July 1, for a whole-time day course in electrical engineering at an approved university or technical college; William Beedie Esson Scholarship (value $£ 120$ per annum, tenable for two years, renewable in approved cases for a third year), for works' employees who are the sons of parents of limited means, open to British subjects less than twenty-two years of age on July 1, for a whole-time day course in electrical engineering at an approved university or technical college. Further information can be obtained from the Secretary, Institution of Electrical Engineers, Savoy Place, London, W.C.2.

\section{Royal Society of Edinburgh: New Fellows}

THe following have been elected fellows of the Royal Society of Edinburgh : Mr. E. B. Ball, president of the Institution of Mechanical Engineers; Mr. J. Bowman, City water engineer, Edinburgh; Mr. B. S. Bramwell, advocate, London; Mr. J. Brough, lecturer in vertebrate zoology, University of Edinburgh; Dr. A. F. Buchan, teacher of mathematics, James Gillespie's School, Edinburgh ; Mr. J. M. Caie, deputy secretary, Department of Agriculture for 